\title{
Perbedaan Kadar Trigliserida pada Perokok Aktif dan Perokok Pasif di RT 06 dan RT 08 Lingkungan II Kelurahan Gunung Mas Kecamatan Teluk Betung Selatan
}

\author{
Heriyansyah $^{1}$, Iwan Sariyanto ${ }^{2}$ \\ ${ }^{1}$ Prodi Diploma IV Analis Kesehatan Politeknik Kesehatan Tanjungkarang \\ ${ }^{2}$ Jurusan Analis Kesehatan Politeknik Kesehatan Tanjungkarang
}

\begin{abstract}
Abstrak
Rokok mengandung berbagai macam unsur berbahaya salah satunya yaitu nikotin. Nikotin menstimulasi sistem simpatis adrenal sehingga menyebabkan peningkatan sekresi hormon katekolamin yang berakibat terjadinya peningkatan lipolisis sehingga menyebabkan peningkatan konsentrasi asam lemak bebas, laktat dan gliserol. Hati akan menggunakan sebagian asam lemak ini untuk membentuk trigliserida yang kemudian digunakan untuk membentuk VLDL. VLDL tidak disimpan di hati tetapi disekresikan kedalam darah, sehingga konsentrasinya di dalam darah meningkat. Nikotin juga dalam jangka waktu panjang mengurangi aliran darah koroner, menurunkan suhu kulit, menyebabkan vasokonstriksi sistemik, meningkatkan aliran darah ke otot dan meningkatkan asam lemak bebas, laktat dan gliserol oleh karenanya dapat meningkatkan kadar trigliserida darah. Penelitian ini bertujuan untuk mengetahui perbedaan kadar trigliserida pada perokok aktif dan perokok pasif di RT 06 dan RT 08 Lingkungan II Kelurahan Gunung Mas Kecamatan Teluk Betung Selatan Bandar Lampung. Jenis penelitian ini bersifat analitik dengan rancangan penelitian Cross Sectional. Variabel bebas pada penelitian ini yaitu perokok aktif dan perokok pasif dengan variabel terikat yaitu kadar trigliserida dalam darah. Analisa menggunakan uji $\mathrm{T}$ Independent. Hasil penelitian didapatkan rata-rata kadar trigliserida pada perokok aktif sebesar $177,79 \mathrm{mg} / \mathrm{dl}$, sedangkan pada perokok pasif didapatkan sebesar 117,81 mg/dl dan terdapat perbedaan yang bermakna kadar trigliserida pada perokok aktif dan perokok pasif dengan nilai p value $0,00<\alpha(0,00<$ $0,05)$.
\end{abstract}

Kata kunci : Perokok Aktif, Perokok Pasif, Trigliserida

\section{Differences in Levels of Triglycerides in Active Smokers and Passive Smokers in RT 06 and RT 08 Lingkungan II Kelurahan Gunung Mas Kecamatan Teluk Betung Selatan}

\begin{abstract}
Cigarettes contain a variety of harmful elements one of them is nicotine. Nicotine stimulates the adrenal sympathetic system resulting in increased secretion of the catecholamine hormone resulting in increased lipolysis leading to increased concentrations of free fatty acids, lactate and glycerol. The liver will use some of these fatty acids to form triglycerides which are then used to form VLDL. VLDL is not stored in the liver but is secreted into the blood, so the concentration in the blood increases. Nicotine also in the long term reduces coronary blood flow, lowers skin temperature, causes systemic vasoconstriction, increases blood flow to the muscles and increases free fatty acids, lactate and glycerol thereby increasing blood triglyceride levels. This study aims to determine differences in triglyceride levels in active smokers and passive smokers in RT 06 and RT 08 Neighborhood II Kelurahan Gunung Mas District Teluk Betung Selatan Bandar Lampung. This research type is analytic with Cross Sectional research design. Independent variable in this research is active smoker and passive smoker with dependent variable that is triglyceride level in blood. Analysis using Independent $\mathrm{T}$ test. The results of the research showed that the average triglyceride level in the active smokers was $177,79 \mathrm{mg} / \mathrm{dl}$, while the passive smoke was found at $117,81 \mathrm{mg} / \mathrm{dl}$ and there was significant difference of triglyceride level on active smoker and passive smoker with $\mathrm{p}$ value $0,00<\alpha(0.00<0.05)$.
\end{abstract}

Keywords: Active Smokers, Passive Smokers, Triglycerides

Korespondensi : Iwan Sariyanto, S.ST, M.Si, Jurusan Analis Kesehatan Politeknik Kesehatan Tanjungkarang, J1 Soekarno Hatta No.1 Bandar Lampung, Mobile 08127938215, e-mail : sariyantoiwan@yahoo.co.id 


\section{Pendahuluan}

Rokok merupakan gulungan tembakau yang besarnya kurang lebih sebesar kelingking yang umumnya dibungkus kertas. Biasanya rokok dijual dalam bungkusan berbentuk kotak atau kemasan kertas yang mudah dimasukkan ke dalam kantong. Sejak beberapa tahun terakhir, bungkusan tersebut juga disertai pesan kesehatan yang memperingatkan perokok terhadap bahaya kesehatan yang dapat ditimbulkan dari merokok.(Aula L.E, 2010).

Di Indonesia perokok berusia lebih dari 10 tahun merokok 12,3 batang perhari (setara satu bungkus). Jumlah terbanyak ditemukan di Bangka Belitung (18 batang). Perokok setiap hari terbanyak ditemukan di Kepulauan Riau sebesar 27,2 \% dan pada persentase perokok setiap hari di Lampung termasuk tertinggi berada pada urutan 7 dari 33 provinsi di indonesia yaitu sebesar 26,5\%. Perokok dengan usia lebih dari 15 tahun meningkat dari $34,2 \%$ tahun 2007 menjadi $36,3 \%$ pada tahun 2013. Usia 30-34 tahun mempunyai proporsi terbesar dengan jumlah 33,4\%. Perokok lakilaki lebih banyak yaitu $47 \%$ dibandingkan dengan perempuan sebanyak $1,1 \%$. Nelayan, buruh dan petani merupakan kelompok perokok aktif terbesar yaitu $44,5 \%$ dibandingkan kelompok pekerjaan yang lain di Indonesia (Riskesdas, 2013).

Rokok menyebabkan 1 dari 10 kematian orang dewasa di seluruh dunia, dan mengakibatkan 5,4 juta kematian pada tahun 2006. Ini berarti bahwa rata-rata ada satu kematian setiap 6,5 detik. Kematian pada tahun 2020 akan mendekati 2 kali jumlah kematian saat ini, jika kebiasaan merokok terus berlanjut (Aula, L.E, 2010).

Rokok diibaratkan sebuah pabrik bahan kimia. Dikarenakan dalam satu batang rokok yang dihisap akan dikeluarkan sekitar 4.000 bahan kimia berbahaya, diantaranya yang paling berbahaya adalah Nikotin, Tar dan Carbon Monoksida (CO). Nikotin menyebabkan ketagihan dan merusak jantung dan aliran darah. Tar menyebabkan kerusakan sel paru-paru dan kanker. Gas $\mathrm{CO}$ menyebabkan berkurangnya kemampuan darah membawa oksigen, sehingga sel-sel tubuh akan mati (Proverawati, 2012).

Dampak merokok terhadap tubuh yaitu kemungkinan mengalami serangan kanker paru, kanker payudara, kanker ginjal, kanker pankreas dan kanker otak karena memperoleh nikotin dari asap rokok, kemungkinan terkena penyakit jantung dan pembuluh darah (stroke), kemungkinan mengalami serangan asma, kemungkinan terkena gangguan kognitif dan dementia (mudah lupa), wanita hamil berkemungkinan melahirkan bayi premature atau bayi lahir cukup bulan, tetapi berat badan kurang dari normal, mudah terkena serangan infeksi di hidung dan tenggorokan, anak-anak mudah terserang asma, meninggal pada usia muda, infeksi paru-paru, mudah mengalami alergi dan gampang terkena TBC paru-paru (Aula, L.E, 2010).

Rokok mengandung berbagai macam unsur yang berbahaya salah satu unsur utamanya yaitu nikotin. Nikotin menstimulasi sistem simpatis adrenal sehingga menyebabkan peningkatan sekresi hormon katekolamin yang berakibat terjadinya peningkatan lipolisis sehingga menyebabkan peningkatan konsentrasi asam lemak bebas (Mustikaningrum, 2010).

Peningkatan lipolisis menyebabkan asam lemak bebas didalam darah meningkat. Hati selanjutnya menggunakan sebagian asam lemak ini untuk membentuk triasilgliserol yang kemudian digunakan untuk membentuk VLDL. VLDL tidak disimpan di hati tetapi disekresikan kedalam darah, sehingga konsentrasinya di dalam serum meningkat (Marks, 2014). Nikotin dapat meningkatkan denyut jantung, tekanan darah, mengurangi aliran darah koroner, menurunkan suhu kulit, meningkatkan darah ke otot, meningkatkan sirkulasi asam lemak bebas, laktat dan gliserol (Joewana, 2005).

Perokok aktif adalah seseorang yang merokok setiap hari dalam jangka waktu minimal enam bulan selama hidupnya dan masih merokok pada saat dilakukan penelitian (Depkes, 2004). Perokok pasif adalah mereka yang tinggal di sekitar perokok dan mempunyai risiko menderita penyakit akibat merokok sama besarnya dengan perokok itu sendiri (Joewana, 2005).

Berdasarkan hasil penelitian Wowor dkk (2012) terdapat perbedaan yang bermakna antara kadar trigliserida darah pada pria perokok dan bukan perokok. Demikian juga penelitian yang dilakukan oleh Mustikaningrum (2010) terdapat perbedaan yang bermakna kadar trigliserida darah pada perokok dan bukan perokok (Mustikaningrum, 2010). Sedangkan berdasarkan penelitian yang dilakukan oleh Puspitawati (2012) pada karyawan RSUD MayJen H.M Ryacudu Kotabumi Lampung Utara tahun 2012 terdapat hubungan antara lama merokok, jumlah rokok dan jenis rokok terhadap peningkatan kadar trigliserida. 
Berdasarkan data kependudukan di RT 08 Lingkungan II Kelurahan Gunung Mas Kecamatan Teluk Betung Selatan total penduduk berjumlah 130 orang dengan jenis kelamin laki-laki sebanyak 81 orang dengan perokok aktif sebanyak $80 \%$ dan sebagian besar berprofesi sebagai buruh dan mempunyai kebiasaan merokok yang dilakukan baik ketika bekerja maupun dirumah. Berdasarkan klasifikasi menurut golongan umur. Laki-laki yang berusia diatas 30 tahun berjumlah 66 orang dan perempuan yang berusia diatas 30 tahun berjumlah 35 orang dengan jumlah perokok pasif sebanyak 90\%. Keluarga dari perokok aktif tersebut berpendapat bahwa mereka tidak merokok tetapi terpaksa menghirup asap rokok yang dihembuskan oleh keluarga yang ada didekatnya.

Berdasarkan masalah di atas, maka penulis melakukan penelitian tentang Perbedaan kadar Trigliserida pada perokok aktif dan perokok pasif di RT 06 dan RT 08 Lingkungan II Kelurahan Gunung Mas Kecamatan Teluk Betung Selatan.

\section{Metode}

Jenis penelitian ini bersifat analitik dengan rancangan Cross Sectional. variabel bebas pada penelitian ini yaitu perokok aktif dan perokok pasif dengan variabel terikat yaitu kadar trigliserida dalam darah.

Lokasi penelitian di lakukan di RT 06 dan RT 08 Lingkungan II Kelurahan Gunung Mas Kecamatan Teluk Betung Selatan. Tempat penelitian dilakukan di Laboratorium Kimia Klinik Jurusan Analis Kesehatan Politeknik Kesehatan Tanjungkarang dan dilakukan pada bulan Maret sampai Juni 2017.

Populasi dari penelitian ini adalah semua warga perokok aktif dan perokok pasif di RT 06 dan RT 08 Lingkungan II Kelurahan Gunung Mas Kecamatan Teluk Betung Selatan dengan jumlah populasi 273 orang.

Sampel diambil dari populasi yang memenuhi kriteria sebanyak 67 orang responden dengan jumlah perokok aktif 35 orang dan perokok pasif 32 orang, Pada penelitian ini 60 orang yang digunakan sebagai sampel terdiri dari masing-masing 30 orang kelompok perokok aktif dan 30 orang perokok pasif. Teknik pengambilan sampel dengan purposive sampling di RT 06 dan RT 08 LK II Kelurahan Gunung Mas Teluk Betung Selatan dengan criteria:
Kriteria Inklusi perokok aktif :

Telah merokok $>6$ bulan, dan masih aktif merokok ketika penelitian, Usia $\geq 30$ tahun, tidak menderita diabetes melitus.Indeks masa tubuh (IMT) $\leq 25,0 \mathrm{~kg} / \mathrm{m}^{2}$, tidak mengkonsumsi alkohol, bersedia menjadi responden. Sedangkan kriteria inklusi perokok pasif : tidak merokok, usia $\geq 30$ tahun., memiliki anggota keluarga sebagai perokok aktif, tidak menderita diabetes mellitus, Indeks masa tubuh (IMT) $\leq$ $25,0 \mathrm{~kg} / \mathrm{m}^{2}$, idak mengkonsumsi alkohol, bersedia menjadi responden.

\section{Hasil}

Analisa Univariat

Tabel 1. Profil kadar trigliserida pada perokok aktif dan perokok pasif pada warga RT 06 dan RT 08 Lingkungan II Kelurahan Gunung Mas Kecamatan Teluk Betung Selatan.

\begin{tabular}{ccccc}
\hline & \multicolumn{4}{c}{ Kadar Trigliserida } \\
\cline { 2 - 5 } Variabel & Rata-rata & SD & $\begin{array}{c}\text { Kadar } \\
\text { Terendah }\end{array}$ & $\begin{array}{c}\text { Kadar } \\
\text { Tertinggi }\end{array}$ \\
\hline $\begin{array}{c}\text { Perokok } \\
\text { Aktif }\end{array}$ & 177,79 & 58,98 & 91,50 & 325,70 \\
$\begin{array}{c}\text { Perokok } \\
\text { Pasif }\end{array}$ & 117,81 & 33,35 & 72,90 & 214,10 \\
\hline
\end{tabular}

Berdasarkan tabel 1 diatas, pada perokok aktif didapatkan rata-rata kadar trigliserida adalah $177,79 \mathrm{mg} / \mathrm{dL}$, SD 58,98 mg/dL, dengan kadar terendah 91,50 mg/dL dan kadar tertinggi $325,70 \mathrm{mg} / \mathrm{dL}$. Sedangkan perokok pasif didapatkan rata-rata kadar trigliserida adalah $117,81 \mathrm{mg} / \mathrm{dL}$, SD 33,35 mg/dL, dengan kadar terendah $72,90 \mathrm{mg} / \mathrm{dL}$ dan kadar tertinggi $214,10 \mathrm{mg} / \mathrm{dL}$.

Analisa Bivariat

Tabel 2. Perbedaan kadar trigliserida pada perokok aktif dan perokok pasif

\begin{tabular}{cccccc}
\hline Trigliserida & $\begin{array}{c}\text { Rata- } \\
\text { rata }\end{array}$ & SD & $\begin{array}{c}\text { SE } \\
\text { rata- } \\
\text { rata }\end{array}$ & N & $\begin{array}{c}p- \\
\text { Value }\end{array}$ \\
\hline Perokok & 177,79 & 58,98 & $\begin{array}{c}10,7 \\
6\end{array}$ & 30 & \\
Aktif & & & 6,08 & 30 & 0.00 \\
$\begin{array}{c}\text { Perokok } \\
\text { Pasif }\end{array}$ & 117,81 & 33,35 & 6,08 & \\
\hline
\end{tabular}

Dari tabel 2 menunjukkan bahwa hasil nilai $p$-value $0.00(\mathrm{p}<0,05)$ dengan demikian terdapat perbedaan yang bermakna, antara kadar trigliserida pada perokok aktif dan perokok pasif di RT 06 dan RT 08 LK II Kelurahan Gunung Mas Kecamatan Teluk Betung Selatan. 


\section{Pembahasan}

Rata-rata kadar trigliserida pada perokok aktif adalah 177,79 $\mathrm{mg} / \mathrm{dl}$ dengan kadar terendah $91,50 \mathrm{mg} / \mathrm{dl}$ dan kadar tertinggi $325,70 \mathrm{mg} / \mathrm{dl}$. Sedangkan perokok pasif didapatkan rata-rata kadar trigliserida adalah $117,81 \mathrm{mg} / \mathrm{dl}$ dengan kadar terendah 72,90 $\mathrm{mg} / \mathrm{dl}$ dan kadar teringgi 214,10 $\mathrm{mg} / \mathrm{dl}$. Berdasarkan analisa data terdapat perbedaan yang bermakna kadar trigliserida pada perokok aktif dan perokok pasif di RT 06 dan RT 08 LK II Kelurahan Gunung Mas Kecamatan Teluk Betung Selatan dengan $p$-Value $0,00(\mathrm{p}<0,05)$.

Dalam rokok terdapat dua jenis asap rokok yang bisa dihisap oleh seorang yaitu asap rokok utama (mainstream) dan asap rokok sampingan (sidestream). Asap rokok utama yaitu asap rokok yang dihisap oleh seseorang langsung dari rokok. Perokok aktif menghirup asap yang sebelumnya telah melewati filter rokok yang dimaksudkan untuk menghilangkan beberapa senyawa tar dan nikotin. Ketika seorang perokok aktif menghembuskan asap rokoknya, maka orang-orang perokok pasif yang berada di sekitarnya akan menghisap asap mainstream yang sudah melalui paru-paru perokok aktif. Sedangkan asap rokok sidestream yaitu asap rokok yang berasal dari ujung rokok yang terbakar dan oleh karena kebanyakan dari pembakaran ini terjadi pada suhu yang lebih rendah daripada asap rokok mainstream. Dengan demikian perokok aktif lebih banyak terpapar asap rokok dari pada perokok pasif. Selain itu intensitas pertemuan antara perokok aktif dan pasif tidak sering sehingga menyebabkan paparan asap rokok berbeda pada kedua kelompok tersebut. Hal ini terjadi karena perokok aktif selain merokok bersama perokok pasif yang sebagian besar berada dalam satu rumah juga merokok pada saat bekerja diluar rumah.

Hasil penelitian Wowor dkk (2012) menunjukkan terdapat perbedaan yang bermakna antara kadar trigliserida darah pada pria perokok dan bukan perokok $(\mathrm{p}<0,026)$. Demikian juga penelitian yang dilakukan oleh Mustikaningrum (2010) menunjukkan terdapat perbedaan yang bermakna kadar trigliserida darah pada perokok dan bukan perokok $(\mathrm{p}<0,001)$. Dengan demikian menunjukkan bahwa intensitas paparan asap rokok menyebabkan perbedaan kadar trigliserida.

Didalam rokok terdapat kandungan zat yang berbahaya, diantaranya adalah nikotin, tar dan carbon monoksida (CO). Nikotin menyebabkan ketagihan, merusak jantung dan aliran darah. Tar menyebabkan kerusakan sel paru-paru dan kanker. Gas CO menyebabkan berkurangnya kemampuan darah membawa oksigen, sehingga sel-sel tubuh akan mati (Proverawati, 2012).

Peningkatan kadar trigliserida pada perokok dikarenakan dalam kandungan rokok terdapat nikotin. Nikotin menstimulasi sistem simpatis adrenal sehingga menyebabkan peningkatan sekresi hormon katekolamin yang berakibat terjadinya peningkatan lipolisis sehingga menyebabkan peningkatan konsentrasi asam lemak bebas, laktat dan gliserol. Peningkatan lipolisis menyebabkan asam lemak bebas didalam darah meningkat (Joewana, 2005).

Trigliserida digunakan dalam tubuh untuk menyediakan energi bagi berbagai proses metabolisme, fungsi lipid ini mempunyai peranan yang hampir sama dengan karbohidrat. Apabila kelebihan kadar trigliserida dapat mengganggu berbagai proses metobolisme dalam tubuh. Timbunan lemak yang terdapat pada pembuluh darah jantung, membuat pembuluh darah tersebut menjadi sempit sehingga dapat menurunkan kemampuan jantung untuk membawa dan menyalurkan oksigen ke seluruh tubuh (Guyton, 1990).

Apabila seseorang yang memiliki kadar trigliserida yang tinggi sebaiknya mengkonsumsi makanan berserat, berolaharga secara teratur, pola hidup sehat dan mengurangi makanan berlemak. Faktor faktor yang dapat meningkatkan kadar trigliserida terbagi menjadi 2 macam, yaitu faktor risiko eksternal dan internal. Faktor risiko eksternal yaitu konsumsi gizi, diabetes melitus, obesitas, alkohol, rokok, stres dan aktifitas fisik. Pada penelitian ini faktor eksternal seperti diabetes melitus, obesitas dan alkohol dapat dikendalikan karena responden yang mengalami keadaan tersebut tidak digunakan pada penelitian. Sedangkan faktor eksternal seperti konsumsi gizi, stres dan aktifitas fisik tidak diperhatikan, sehingga diperkirakan faktor ini yang dapat menyebabkan kadar trigliserida responden tetap normal. Dengan demikian terjadinya peningkatan kadar trigliserida selain oleh rokok dapat juga dipengaruhi faktor-faktor tersebut. Hal ini menjadi keterbatasan pada penelitian ini.

Faktor risiko internal yang dapat meningkatkan kadar trigliserida yaitu usia, jenis kelamin dan riwayat keluarga juga tidak diperhatikan pada penelitian ini sehingga menjadi keterbatasan penelitian ini. 


\section{Daftar Pustaka}

1. Aula, LE 2010, Stop Merokok!, Garailmu, Yogyakarta.

2. Badan Penelitian dan Pengembangan Kesehatan Kementerian Kesehatan RI tahun 2013, Riset Kesehatan Dasar.

3. Departemen Kesehatan Republik Indonesia 2004, Konsumsi Rokok dan Prevalensi Merokok, Departemen Kesehatan Republik Indonesia, Jakarta.

4. Guyton, AC 1990, Fisiologi manusia dan mekanisme penyakit, alih bahasa Petrus Andrianto - ed.3, EGC, Jakarta.

5. Joewana, MDS 2005, Gangguan mental dan perilaku akibat penggunaan zat psikoaktif. Penyalahgunaan NAPZA/ Narkoba Ed.2, EGC, Jakarta.

6. Marks, DB, Marks, AD, Smith, CM 2014, Biokimia Kedokteran Dasar, di terjemahkan oleh dr. Brahm U. Pendit, Buku Kedokteran EGC, Jakarta.
7. Mustikaningrum, S 2010, Perbedaan Kadar Trigliserida Darah Pada Perokok dan Bukan Perokok, Fakultas Kedokteran Universitas Sebelas Maret, Jawa Tengah.

8. Proverawati, A, Rahmawati, E 2012, Perilaku Hidup Bersih dan Sehat (PHBS), Nuha Medika, Yogyakarta.

9. Puspitawati, Tita 2012, Hubungan Lama Merokok, Jumlah Rokok dan Jenis Rokok dikonsumsi dengan Peningkatan Kadar Trigliserida Pada Karyawan di RSUD Mayjend H.M Ryacudu Lampung Utara, Poltekkes Tanjungkarang, Lampung.

10. Wowor, FJ, Ticoalu, SHR, dan Wongkar, D 2012, Perbandingan Kadar Trigliserida Darah Pada Pria Perokok dan Bukan Perokok, Universitas Sam Ratulangi, Manado. 